\title{
CHEMICAL SENSORS
}

\section{XIMIYHI CEHCOPИ}

PACS: 71.24.+q; 78.55.Mb; 78.66.w; УДК 621.315.592

DOI http://dx.doi.org/10.18524/1815-7459.2017.1.96436

\section{ОСОБЛИВОСТІ ГАЗОЧУТЛИВОСТІ БАРВНИКІВ НА БАЗІ КОМПЛЕКСІВ 4-ВАЛЕНТНОГО СТАНУМУ}

\author{
I. К. Дойчо ${ }^{1}$, С. А. Гевелюк², Я. І. Лепіх \\ ${ }^{1}$ Одеський національний університет імені I. I. Мечникова, вул.Дворянська, 2, 65026, Одеса, \\ Україна, тел.+38(0482)498750, e-mail: viknawsvit@gmail.com \\ ${ }^{2}$ Одеський національний університет імені I. I. Мечникова, вул.Дворянська, 2, 65026, Одеса, \\ Україна, тел.+38(0482)526412, e-mail: gevelyuks@gmail.com \\ ${ }^{3}$ Одеський національний університет імені I. I. Мечникова, вул.Дворянська, 2, 65026, Одеса, \\ Україна, тел.+38(048)7233461, e-mail: ndl_lepikh@onu.edu.ua \\ ${ }^{4}$ Інститут фізики Вроцлавської політехніки, узб. Вишьпяньскего, 27, 50370, Вроцлав, Польща, \\ тел.+48(502)120108, e-mail: Ewa.Rysiakiewicz-Pasek@pwr.edu.pl
}

\section{ОСОБЛИВОСТІ ГАЗОЧУТЛИВОСТІ БАРВНИКІВ НА БАЗІ КОМПЛЕКСІВ 4-ВАЛЕНТНОГО СТАНУМУ}

\author{
I. К. Дойчо, С. А. Гевелюк, Я. І. Лепіх, Е. Ришякевич-Пасек
}

\begin{abstract}
Анотація. Досліджено вплив наявності у довкіллі аміаку або парів хлористого водню на фотолюмінесцентні властивості ансамблю наночастинок барвників на базі комплексів 4-валентного стануму. Виявлено, що чутливими до аміаку є барвники, що містять аміновий замісник бензоїльного типу у гідразонному фрагменті, а до хлористого водню - барвники із гідроксильним замісником. Обидві групи сполук суттєво зменшують інтенсивність свого світіння при наявності у
\end{abstract}

(C) I. К. Дойчо, С. А. Гевелюк, Я. І. Лепіх, Е. Ришякевич-Пасекч, 2017 
довкіллі відповідного газу. Послаблення світіння є досить стійким і поновлення люмінесцентних властивостей зразка можливе лише внаслідок низькотемпературного відпалу.

Ключові слова: барвники, фотолюмінесценція, аміак, хлористий водень, давачі газу, екологія

\title{
FEATURES OF GAS-SENSIBILITY OF DYES ON THE BASE OF 4-VALENCE STANNUM COMPLEXES
}

\author{
I. K. Doycho, S. A. Gevelyuk, Ya. I. Lepikh, E. Rysiakiewicz-Pasek
}

\begin{abstract}
Influence of ammonia or hydrogen chloride vapour in environment on the photoluminescence properties of nanoparticles ensemble of dyes on the base of 4-valence stannum complexes is researched. It is found that the dyes containing amine substituent in the hydrazone fragment are sensible to ammonia, whereas ones containing hydroxyl substitutient are sensible to hydrogen chloride. The luminescence intensity decreases essentially for both groups of compounds if the environment contents the suitable gas. Weakening of illumination is sufficiently stable and restoration of luminescence properties of sample is able after low-temperature anneal only.
\end{abstract}

Keywords: dyes, photoluminescence, ammonia, hydrogen chloride, gas sensors, ecology

\section{ОСОБЕННОСТИ ГАЗОЧУВСТВИТЕЛЬНОСТИ КРАСИТЕЛЕЙ НА ОСНОВЕ КОМПЛЕКСОВ 4-ВАЛЕНТНОГО ОЛОВА}

\author{
И. К. Дойчо, С. А. Гевелюк, Я. И. Лепих, Э. Рьиякевич-Пасек
}

\begin{abstract}
Аннотация. Исследовано влияние наличия в окружающей среде аммиака или паров хлористого водорода на фотолюминесцентные свойства ансамбля наночастиц красителей на основе комплексов 4-валентного олова. Обнаружено, что чувствительны к аммиаку красители, содержащие аминовый заместитель в гидразонном фрагменте, а к хлористому водороду красители с гидроксильным заместителем. Обе группы соединений существенно уменьшают интенсивность своего свечения при наличии в окружающей среде соответствующего газа. Ослабление свечения является достаточно устойчивым и восстановление люминесцентных свойств образца возможно лишь после низкотемпературного отжига.

Ключевые слова: красители, фотолюминесценция, аммиак, хлористый водород, газовые датчики, экология
\end{abstract}




\section{Вступ}

3 літературних джерел відомо [1], що барвники на базі комплексів 4-валентного стануму змінюють свої люмінесцентні властивості залежно від газового складу оточуючої атмосфери. Проте, барвник у розчині є відокремленим від довкілля судиною, що має зменшувати зазначену чутливість. До того ж, центри люмінесценції барвника концентруються на поверхні його молекул [2] і світіння відбувається за рахунок їхньої взаємодії із молекулами розчинювача. 3 іншого боку, молекули розчинювача пасивують поверхню молекул барвника, що також зменшує його газочутливість. Через це барвники у розчині недоцільно використовувати у якості газових сенсорів. Попри зазначене, наші останні дослідження продемонстрували [3-6], що барвник є спроможним світитися не лише в розчині, але й у вигляді ансамблю наночастинок у шпаристій матриці, яка у цьому випадку відіграє роль своєрідної системи нанорозмірних «пробірок». Такою матрицею може бути шпаристе силікатне скло слушного типу $[5,7]$, яке є хімічно інертним, досить тривким і не люмінесціює в діапазоні довжин хвиль, у якому світиться барвник. При цьому інтенсивність світіння барвника виявляється завжди більшою, аніж у відповідному розчині [5-6], що, по-перше, пов'язане із унеможливленням агрегування частинок барвника всередині шпарин, забруднених силікагелем [8-9], а, по-друге, iз унеможливленням поглинання квантів випроміненого світла розчинником через відсутність останнього. Всередині шпарин речовина барвника диспергується практично до молекулярного рівня, що полегшує частинкам газу, що міститься у довкіллі, взаємодію iз центрами світіння. Отже, наночастинки барвника безпосередньо контактують із довкіллям і можуть реагувати на зміни його складу.

На базі комплексів 4-валентного стануму існує кілька десятків барвників, що відрізняються координаційним вузлом, типом і складом замісника у гідразонному фрагменті, а також його таутометричною формою [5]. Координаційний вузол, зазвичай, являє складну систему хімічно досить інертних бензольних кілець і ліганда на базі Sn та Cl. Зазначені ліганди мають цвітер-йону будову, тобто являють в цілому електро-нейтральну молекулу, яка, проте, у деяких своїх частинах несе як негативний, так і позитивний заряд, що їх локалізовано на несусідніх атомах. У залежності від дентантності ліганда розрізняють 2 типи координаційних вузлів: $\left\{\mathrm{SnCl}_{4} \mathrm{ON}\right\}$, у якому негативний заряд однодентантного ліганду локалізовано на атомі $\mathrm{N}$ (у подальшому $\left\{\mathrm{SnCl}_{4}\right\}$ ), та $\left\{\mathrm{SnCl}_{3} \mathrm{O}_{2} \mathrm{~N}\right\}$ iз негативним зарядом дводентантного ліганду, що його локалізовано на атомах $\mathrm{N}$ та $\mathrm{O}$ (у подальшому $\left.\left\{\mathrm{SnCl}_{3}\right\}\right)$. Відповідні структурні формули зображено на Рис. 1, де локалізацію зарядів позначено стрілкою.

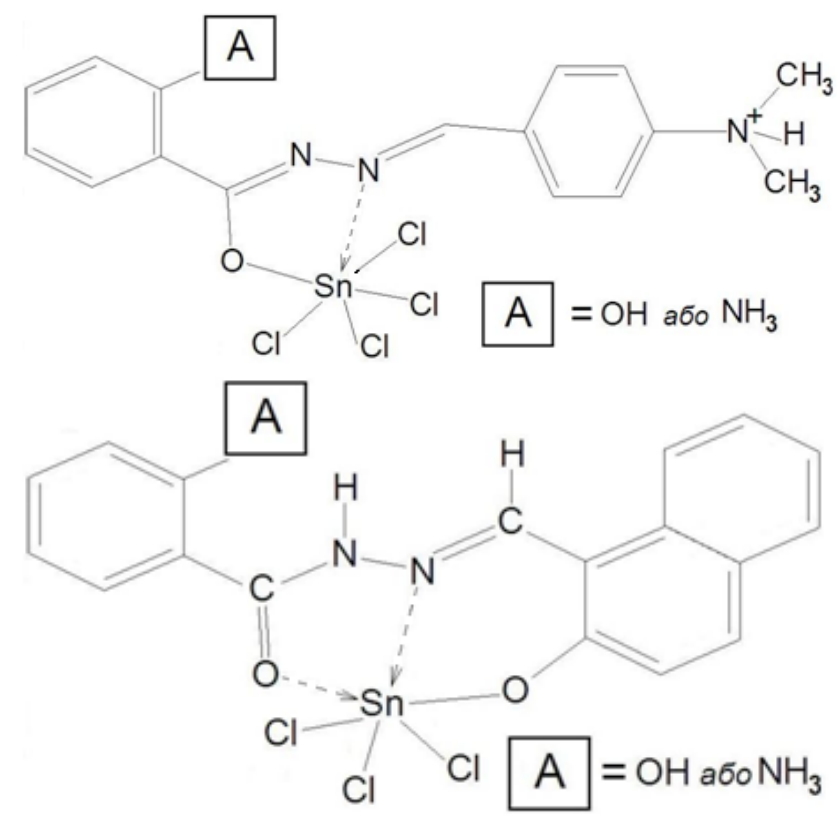

Рис. 1. Будова барвників із координаційним вузлом $\left\{\mathrm{SnCl}_{4}\right\}$ (вгорі) або $\left\{\mathrm{SnCl}_{3}\right\}$ (насподі).

\section{Методика створення зразків}

Для створення ансамблю наночастинок як матриця використовувалося шпаристе скло типу А, що здобувалося 3 двохфазного натрієборосилікатного скла. Фази відокремлювалися шляхом витримування при температурі $763 \mathrm{~K}$ протягом 165 годин і надалі хімічно 
менш стійка натрієборатна фаза усувалася обробкою у $0.5 \mathrm{~N}$ розчині соляної кислоти. Методом унесення маси [7] визначено, що шпаристість отриманого силікатного скла складала 38\%. Розподілення шпарин за розміром визначалося методом адсорбційної шпароскопії [5]. Середній діаметр шпарин складав близько $30 \mathrm{~nm}$, повний середній об'єм порожнин був $292 \mathrm{~mm}^{3} /$, а середня площа розгорнутої поверхні складала близько 54.7 $\mathrm{M}^{2} /$ г. Внаслідок зазначеної хімічної обробки всередині шпарин утворювалася певна кількість дрібнодисперсного залишкового силікагелю $[5,7]$. Здобуте на такий спосіб шпаристе скло насичувалося розчином відповідного барвника у діметилформаміді (DMFA) протягом близько 10-12 годин і надалі піддавалося низькотемпературному відпалу, що забезпечувало досить рівномірний просторовий розподіл наночастинок у шпаринах. Фотолюмінесцентні властивості сформованого ансамблю досліджувалися на стандартній установці [10] зі збудженням спектрів ультрафіолетовим лазером LCS-DTL374QT (довжина хвилі $\lambda=355$ нм, потужність 15 мВт) і відрізнялися в залежності від типу барвника та концентрації насичуючого розчину.

Для вивчення можливої чутливості ансамблів наночастинок барвників досліджуваного типу до присутності аміаку в атмосфері було обране дрібношпаристе силікатне скло із залишковим силікагелем у шпаринах (скло типу А), насичене розчином барвника $2 \mathrm{NH}_{3}\left\{\mathrm{SnCl}_{4}\right\}$ у DMFA із концентрацією $0,5 \times 10^{-3} \Gamma$ Моль/л. Вибір було зроблено з наступних міркувань:

1) скло типу А найкращим чином перешкоджає агрегуванню наночастинок [8];

2) розчинник DMFA має найменшу поглинальну здатність $[5,11]$;

3) саме ця таутометрична форма при насиченні матриці розчином барвника саме із цією концентрацією створює ансамбль наночастинок із максимальною інтенсивністю люмінесценції $[4,5,12]$.

Залежність інтенсивності світіння ансамблю наночастинок на базі $2 \mathrm{NH}_{3}\left\{\mathrm{SnCl}_{4}\right\}$ від концентрації насичуючого розчину наведено на Рис. 2. Видно, що за малих концентрацій розчину інтенсивність світіння незначна, що певне пов'язане із малою кількістю створених частинок барвника, за концентрацією $0,5 \times 10^{-3} \Gamma$ Моль/л інтенсивність $є$ максимальною, а перевищення цієї концентрації призводить до падіння інтенсивності світіння внаслідок концентраційного гасіння [5, 12].

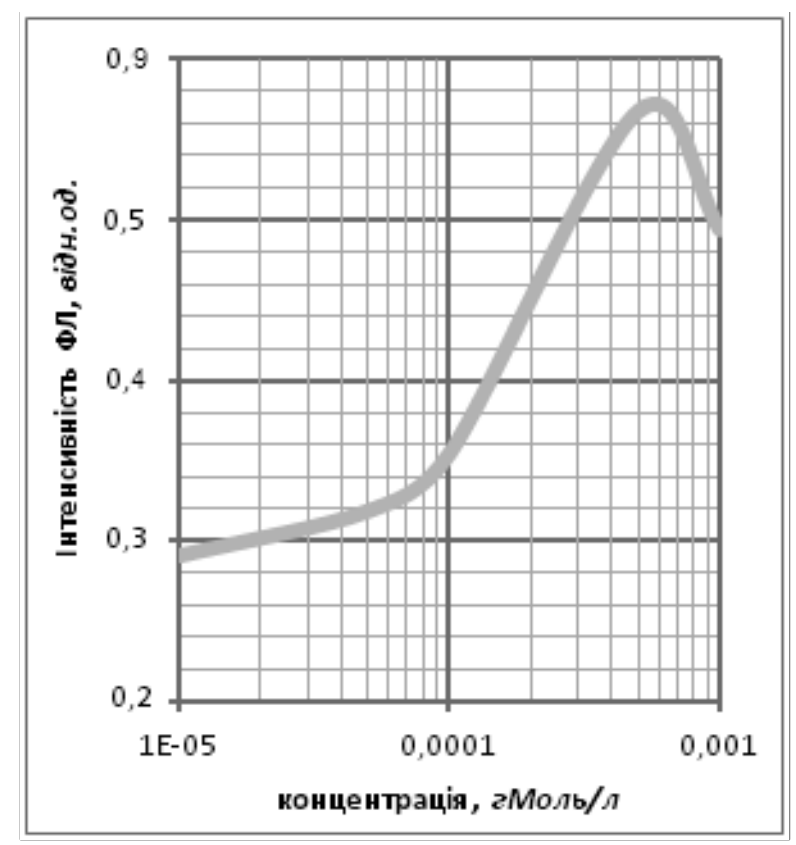

Рис. 2. Залежність інтенсивності світіння ансамблю наночастинок на базі $2 \mathrm{NH}_{3}\left\{\mathrm{SnCl}_{4}\right\}$ від концентрації насичуючого розчину.

\section{Газочутливість до аміаку}

Дослідження продемонстрували, що найбільш чутливими до аміаку є ансамблі наночастинок барвників із аміновим замісником бензоїльного типу у гідразонному фрагменті. У ході експерименту спочатку вимірювалася інтенсивність вихідної люмінесценції ансамблю наночастинок $2 \mathrm{NH}_{3}\left\{\mathrm{SnCl}_{4}\right\}$. Надалі зразок занурявся до атмосфери, що містить аміак, і вимірювання повторювалися одразу після занурення та після 10-тихвилинного витримування у зазначеній атмосфері. Потім зразок переносився у звичайну атмосферу і йому надавався добовий «відпочинок». Далі знов вимірювалася інтенсивність 
його світіння, після чого його піддавали 10-хвилинному низькотемпературному (при $240^{\circ} \mathrm{C}$ ) відпалу. Результат наведено на Рис. 3 у вигляді гістограми. Видно, що барвник після занурення у атмосферу, що містить аміак, різко і стійко зменшує інтенсивність свого світіння і поновити вихідну інтенсивність можна лише після відпалу.

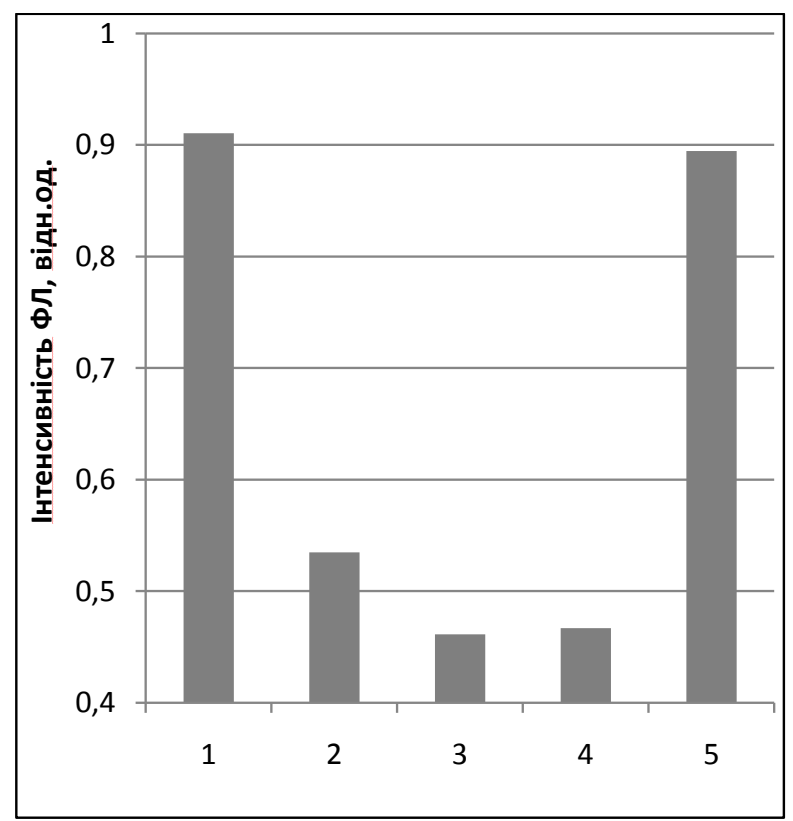

Рис. 3. Залежність інтенсивності люмінесценції ансамблю наночастинок $2 \mathrm{NH}_{3}\left\{\mathrm{SnCl}_{4}\right\}$ від зовнішніх умов:

1 - вихідний зразок перед зануренням до атмосфери, що містить аміак;

2 - в атмосфері, що містить аміак;

3 - за 10 хвилин витримування у атмосфері, що містить аміак;

4 - за 1 добу після вміщення у звичайну атмосферу;

5 - після 10-хвилинного низькотемпературного відпалу.

Для пояснення результату слід згадати, що азот всередині координаційного вузла знаходиться у неактивному стані. Отже можна вважати, що барвник $2 \mathrm{NH}_{3}\left\{\mathrm{SnCl}_{4}\right\}$ первинно містить активний азот (у заміснику). Концентрація розчину, з якого формувався ансамбль наночастинок, відповідала максимуму інтенсивності світіння. Після занурення до аміаку кількість активного азоту в системі збільшилася, і вона почала поводити себе, наче була сформованою з розчину із більш високою концентрацією, що відповідає меншій інтенсивності світіння (як це добре видно 3 Рис. 2). Стійкість змін, ймовірно, пов'язана із утворенням аміаком стійких місткових зв'язків всередині шпарин, які можна було порушити лише відпалом. Ця модель підтверджується практично повною нечутливістю ансамблю наночастинок барвника $2 \mathrm{OH}\left\{\mathrm{SnCl}_{4}\right\}$ при тих самих умовах. Цей барвник первинно не містить активний азот, тож практично не взаємодіє із аміаком.

\section{Газочутливість до хлористого водню}

Дослідження чутливості ансамблів наночастинок барвників на базі комплексів 4-валентного стануму до присутності в атмосфері парів $\mathrm{HCl}$ продемонстрували певну стійкість люмінесцентних властивостей більшості барвників цієї групи. Виняток склали лише сполуки із гідроксильним замісником бензоїльного типу у гідразонному фрагменті. 3 усіх можливих таутометричних форм було обрано ті, що мають найбільшу початкову інтенсивність світіння, а саме $2 \mathrm{OH}\left\{\mathrm{SnCl}_{4}\right\}$ та $2 \mathrm{OH}\left\{\mathrm{SnCl}_{3}\right\}[5-6]$.

На відміну від аміакочутливих сполук, що миттєво реагували на присутність аміаку в атмосфері, чутливість зазначених барвників до парів $\mathrm{HCl}$ мала певний латентний період. Через це методика експерименту була дещо зміненою. Після запису спектру вихідної люмінесценції зразка він занурявся до атмосфери, що містить пари $\mathrm{HCl}$, i витримувався у зазначеній атмосфері протягом півгодини. Надалі спектр люмінесценції зразка знов записувався i результат порівнювався із початковим спектром. Аніякого зсуву максимуму світіння не відбувалося, що є типовим для барвників із гідроксильним замісником [3, 5], проте спостерігалося суттєве зменшення інтенсивності люмінесценції, як добре видно на Рис. 4. Використовуючи цю інформацію, фіксувалася довжина хвилі, якій відповідала максимальна інтенсивність світіння (для барвника $2 \mathrm{OH}\left\{\mathrm{SnCl}_{4}\right\}$ вона складала 510 нм, а для 
барвника $2 \mathrm{OH}\left\{\mathrm{SnCl}_{3}\right\}$, відповідно, 468 нм), i надалі виконувалося вимірювання кінетики іiі зменшення у парах $\mathrm{HCl}$.
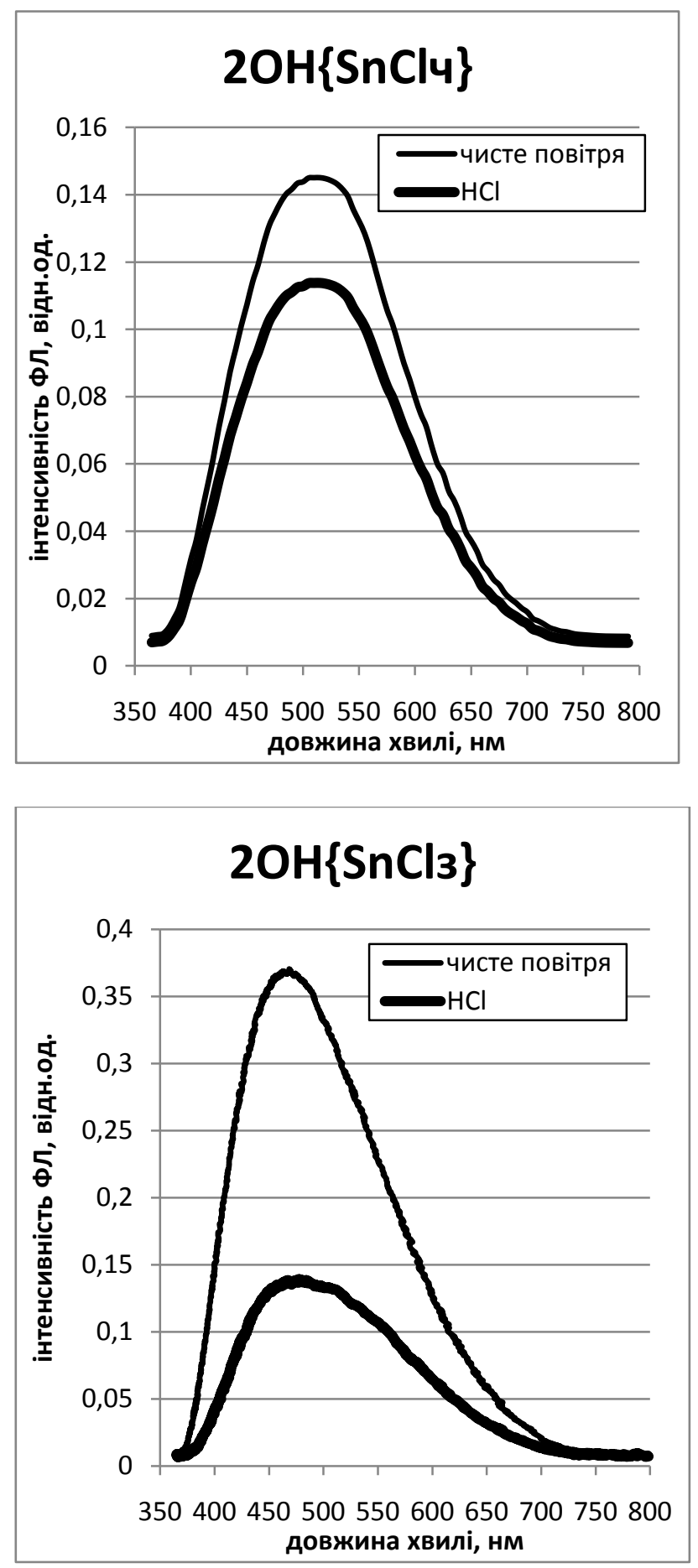

Рис. 4. Змінення спектрів фотолюмінесценції барвників 2OH $\left\{\mathrm{SnCl}_{4}\right\}$ (вгорі) та $2 \mathrm{OH}\left\{\mathrm{SnCl}_{3}\right\}$ (насподі) в атмосфері, що містить пари HCl.

Для барвника $2 \mathrm{OH}\left\{\mathrm{SnCl}_{4}\right\}$ була отримана така картина. Протягом перших 55 секунд сис- тема не відчувала наявності забруднюючої атмосферу речовини і зберігала початкову інтенсивність люмінесценції, а далі досить швидко, протягом 5 секунд відбулося переключення на інтенсивність, яка була їй притаманна в атмосфері, що містить пари $\mathrm{HCl}$ (див. Рис. 5). Тобто ансамбль наночастинок барвника $2 \mathrm{OH}\left\{\mathrm{SnCl}_{4}\right\}$ являє досить швидкодіючу систему, бодай інтенсивність іï світіння зменшилася у парах $\mathrm{HCl}$ лише на $20 \%$.

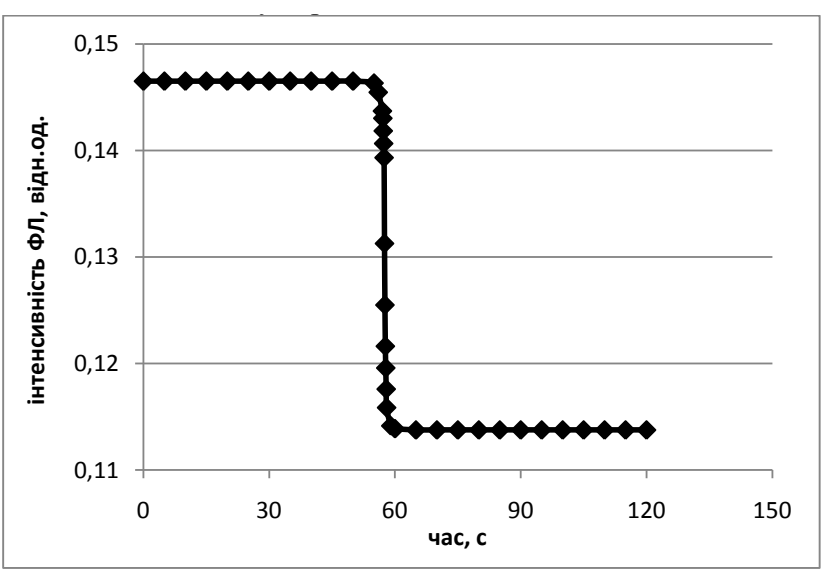

Рис. 5. Кінетика зменшення інтенсивності світіння барвника $2 \mathrm{OH}\left\{\mathrm{SnCl}_{4}\right\}$ у парах $\mathrm{HCl}$.

Для барвника $2 \mathrm{OH}\left\{\mathrm{SnCl}_{3}\right\}$ спостерігалася дещо інша картина. Спочатку майже 10 хвилин система зовсім аніяк не реагувала на наявність в атмосфері парів $\mathrm{HCl}$. Далі інтенсивність світіння системи дуже повільно і «неохоче» почала трохи зменшуватися (від 0,362 до 0,313 відн.од. протягом близько 4 хвилин). І лише після такого, досить тривалого латентного періоду відбулося переключення на інтенсивність, яка була їй притаманна в атмосфері, що містить пари $\mathrm{HCl}$ (див. Рис. 6). Щоправда, здобута досить інерційна система після переключення зменшує інтенсивність свого світіння майже втричі.

Для пояснення результату звернемо увагу, що барвник $2 \mathrm{OH}\left\{\mathrm{SnCl}_{4}\right\}$ початково містить хлор всередині однодентантного ліганда $\mathrm{SnCl}_{4}$ із відповідним розподіленням негативного заряду. Сама система являє шпаристе скло, шпарини якого містять барвник і атмосферне повітря. Після занурення зразка у пари $\mathrm{HCl}$ у його шпаринах опиняються барвник 
і багато йонів хлору. Останні призводять до перерозподілу негативного заряду в системі, що стимулює швидке переключення люмінесценції на меншу інтенсивність. Початковий латентний період відповідає часу, необхідному для витискування атмосферного повітря у шпаринах парами $\mathrm{HCl}$.

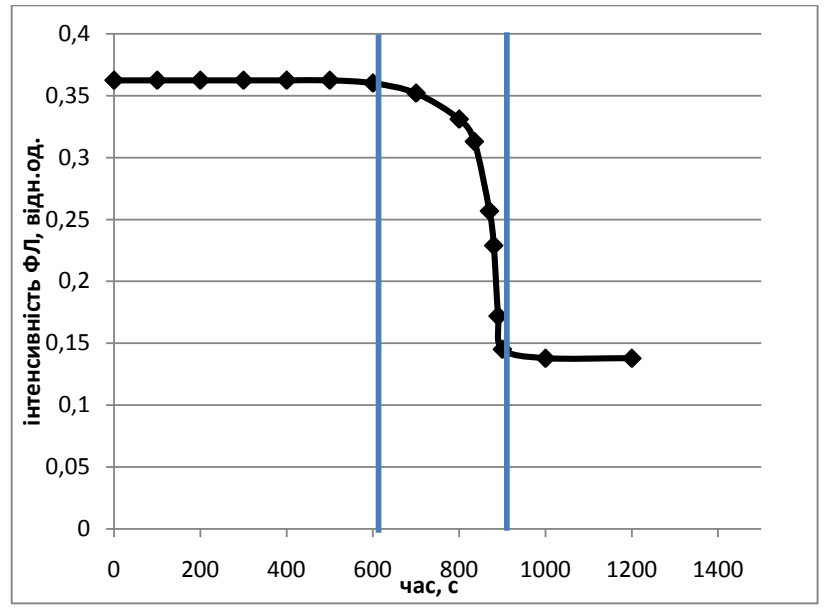

Рис. 6. Кінетика зменшення інтенсивності світіння барвника $2 \mathrm{OH}\left\{\mathrm{SnCl}_{3}\right\}$ у парах $\mathrm{HCl}$.

У разі системи з барвником $2 \mathrm{OH}\left\{\mathrm{SnCl}_{3}\right\}$ хлор початково міститься всередині двохдентантного ліганда $\mathrm{SnCl}_{3}$ і негативний заряд розподілено іншим чином. Після збагачення атмосфери в шпаринах йонами хлору, що досить хімічно активні, вони починають донасичувати ліганд до стану $\mathrm{SnCl}_{4}$, якому відповідає менша інтенсивність світіння. Латентний період при цьому виявляється значно тривалішим, бо крім витискування атмосферного повітря з шпарин має відбутися і зазначений процес. А після його завершення знов відбувається перерозподіл негативного заряду в системі, якій стимулює швидке переключення люмінесценції на меншу інтенсивність.

Слід зазначити, що відбувається певна селективність газочутливості барвників на базі комплексів 4-валентного стануму. Чутливими до аміаку виявляються барвники, що містять активний азот у гідразонному фрагменті. А барвники із гідроксильним замісником залишаються байдужими до наявності аміаку в атмосфері, бо аніяк із ним не взаємодіють. Натомість, чутливими до парів $\mathrm{HCl}$ виявляються барвники із гідроксильним замісником, які зменшують інтенсивність свого світіння завдяки перерозподілу негативного заряду в системі. В той же час для барвників із аміновим замісником зазначений перерозподіл компенсується зсувом максимуму світіння в той або інший бік. А такий зсув може спричинятися не лише перерозподілом заряду, а й багатьма іншими чинниками [5], тож якщо він відбувся, це не обов'язково свідчить про появу парів $\mathrm{HCl}$ в атмосфері, і такі системи непридатні у якості давачів $\mathrm{HCl}$.

\section{Висновки}

Чутливість ансамблю наночастинок барвника до аміаку виявляється у зменшенні інтенсивності його світіння у порівнянні із фотолюмінесценцією у звичайній атмосфері, якщо барвник містить аміновий замісник бензоїльного типу. Ефект певне $\epsilon$ пов'язаним із утворенням місткових зв'язків всередині шпарин матриці.

Чутливість ансамблю наночастинок барвника до парів $\mathrm{HCl}$ виявляється у переключенні люмінесценції системи на меншу інтенсивність завдяки перерозподіленню негативного заряду в ній під дією надлишку йонів хлору, якщо барвник містить гідроксильний замісник бензоїльного типу.

Отже, має місце певна селективність газочутливості барвників на базі комплексів 4-валентного стануму. Чутливими до аміаку і стійкими до парів $\mathrm{HCl}$ виявляються барвники iз аміновим замісником, а чутливими до парів $\mathrm{HCl}$ і стійкими до аміаку є барвники із гідроксильним замісником. Тож перспективно використовувати у якості індикаторного люмінесцентного давача одночасно системи на базі обох ансамблів наночастинок: у разі необхідності кожна спрацює на відповідний газ.

\section{Список використаної літератури}

1. V. A. Bordovskii, A. B. Zharkoi, R. A Kastro, A. V. Marchenko. Svoistva i struktura polimernyh materialov, vkluchaiushchih chetyrohvalentnoe olovo // Izvestia RGPU 
im. A. I. Gercena, 38, pp. 41-50 (2007) (in Russian).

2. Qian Lei, Jin ZhenSheng, Yang ShengYi, $\mathrm{Du}$ ZuLiang, $\mathrm{Xu}$ XuRong. Bright visible photoluminescence from nanotube titania grown by soft chemical process // Chem. Mater., 17, pp. 5334-5338 (2005).

3. N. V. Shmatkova, I. I. Seifullina, I. K. Doycho, S. A. Gevelyuk, R. V. Viter. Fotoluminescencia nanorazmernyh chastic na osnove kompleksov $\mathrm{Sn}(\mathrm{IV})$ s gidrazonami // Spektroskopia koordinacionnyh soedinenii (Materialy X Vserossiiskoi konferencii s mezhdunarodnym uchastiem, 2013, Tuapse, Rossia). pp. 140-142 (2013) (in Russian).

4. N. V. Shmatkova, I. I. Seifullina, I. K. Doycho, S. A. Gevelyuk, V. A. Smyntyna, R. V. Viter. Size effects on photoluminescence spectra of nanoparticles of tin(IV) complexes with hydrazones of 4-dimethylaminobenzaldehyde in silica porous matrix // Prikladnaia fiziko-neorganicheskaia himia (Materialy II Mezhdunarodnoi konferencii, 2013, Sevastopol, Ukraina). DIP, Simferopol, pp. 197-198 (2013).

5. I.K. Doycho.Issledovanie fotoluminescentnyh svoistv ansamblei nanochastic krasitelei. Chap. 3 in Neravnovesnye Processy v Sensornyh Strukturah, Ed. V. A. Smyntyna, pp. 120-170, ONU, Odessa (2015) (in Russian).

6. I. K. Doycho, S.A. Gevelyuk, E. RysiakiewiczPasek. Photoluminescence of tautomeric forms of nanoparticle ensembles of dyes based on the 4-valence stannum complexes in porous silica glass // Photoelectronics, 24, pp. 30-37 (2015).

7. O. V. Mazurin, G. P. Roskova, V. I. Averianov, T. V. Antropova. Dvuhfaznye stokla: struktura, svoistva, primenenie. Nauka, Leningrad. 276 s. (1991) (in Russian).

8. O. V. Tyurin, Y. M. Bercov, S. O. Zhukov, T. F. Levitskaya, S. A. Gevelyuk, I. K. Doycho, E. Rysiakiewicz-Pasek. Dye aggregation in porous glass // Optica Applicata, 40(2), pp. 311-321 (2010).

9. R. V. Viter, S. A. Geveluk, V. A. Smyntyna, I. K. Doycho, E. Rysiakiewicz-Pasek, J. Buk, K. Kordás. Optical properties of nanoporous glass filled with $\mathrm{TiO}_{2}$ nanostructures // Optica Applicata, 42(2), pp. 307-313 (2012).

10. S. A. Gevelyuk, I. K. Doycho, D. V. Lishchuk, L. P. Prokopovich, E. D. Safronsky, E. Rysiakiewicz-Pasek, Y. O. Roizin. Linear extension of porous glasses with modified internal surface in humid environment // Optica Applicata, 30(4), pp. 605-611 (2000).

11. U. D. Rossi, S. Daehne, R. Reisfeld. Photophisical properties of cyanine dyes in sol-gel matrices // Chemical Physics Letters, 251(5-6), pp. 259-267 (1996).

12. S. A. Gevelyuk, E. Rysiakiewicz-Pasek, I. K. Doycho. Dependence of photoluminescence of nanoparticle ensembles of stannum (IV) complexes in silica porous matrix on concentration of saturating solution // Photoelectronics, 25, pp. 40-47 (2016).

Стаття надійшла до редакції 27.02.2017 р. 
PACS: 71.24.+q; 78.55.Mb; 78.66.w; UDC 621.315.592

DOI http://dx.doi.org/10.18524/1815-7459.2017.1.96436

\title{
FEATURES OF GAS-SENSIBILITY OF DYES ON THE BASE OF 4-VALENCE STANNUM COMPLEXES
}

\author{
I. K. Doycho', S. A. Gevelyuk', Ya. I. Lepikh', E. Rysiakiewicz-Pasek ${ }^{2}$ \\ ${ }^{1}$ I. I. Mechnikov National University of Odessa \\ ${ }^{2}$ Institute of Physics, Wrocław University of Technology
}

\begin{abstract}
Summary
Aim: Regularity detecting of possible sensitivity of nanoparticles ensemble of dyes on the base of 4-valence stannum complexes to presence of ammonia or $\mathrm{HCl}$ vapour in environment.

Research methods: Analysis of photoluminescence spectra of specimens with posterior summarizing of obtained experimental results and using the literary data and analogies with results of previous researching.

Results of researching: It's found, that the nanoparticles ensemble of dyes containing the benzoyl type amine substituent in the hydrazone fragment sharp and stably decreases its luminescence intensity about in half after placing into ammonia atmosphere. The initial luminescence intensity may be restored after annealing only. Probably this result is connected with formation of bridge bonds inside the pores of matrix by ammonia molecules. On the other hand, the nanoparticles ensemble of dyes containing the hydroxyl type amine substituent is sensitive to the $\mathrm{HCl}$ vapour. They reduce their luminescence intensity about three times due to redistribution of negative charge in system. However, specified changes have a place with some latent period. The initial luminescence intensity also may be restored after annealing in this case.

Conclusion: There is certain selectivity of gas sensitivity of investigated dyes. The dyes containing amine substituent are sensitive to ammonia and insensitive to $\mathrm{HCl}$ vapour. The dyes containing hydroxyl substituent are sensitive to $\mathrm{HCl}$ vapour and insensitive to ammonia. So it's promise to use as an indicated luminescence gas sensor both systems simultaneously. If it will need, every one snaps into action to appropriate gas.
\end{abstract}

Keywords: dyes, photoluminescence, ammonia, hydrogen chloride, gas sensors, ecology 
PACS: 71.24.+q; 78.55.Mb; 78.66.w; УДК 621.315.592

DOI http://dx.doi.org/10.18524/1815-7459.2017.1.96436

\title{
ОСОБЛИВОСТІ ГАЗОЧУТЛИВОСТІ БАРВНИКІВ НА БАЗІ КОМПЛЕКСІВ 4-ВАЛЕНТНОГО СТАНУМУ
}

\author{
I. К. Дойчо ${ }^{1}$, С. А. Гевелюк', Я. І. Лепіх \\ ${ }^{1}$ Одеський національний університет імені I. I. Мечникова \\ ${ }^{2}$ Інститут фізики Вроилавської політехніки
}

\section{Реферат}

Мета: Виявити закономірності можливої чутливості ансамблів наночастинок барвників на базі комплексів 4-валентного стануму до присутності в атмосфері аміаку або парів хлористого водню.

Методи дослідження: Аналіз спектрів фотолюмінесценції зразків із наступним узагальненням отриманих експериментальних результатів і використанням літературних даних та аналогій 3 результатами попередніх досліджень.

Результати дослідження: Виявлено, що ансамбль наночастинок барвників із аміновим замісником бензоїльного типу у гідразонному фрагменті після занурення у атмосферу, що містить аміак, різко і стійко зменшує інтенсивність свого світіння майже удвічі, і поновити вихідну інтенсивність можна лише після відпалу. Ефект певне є пов'язаним із утворенням молекулами аміаку місткових зв'язків всередині шпарин матриці. Натомість, чутливими до парів $\mathrm{HCl}$ виявляються ансамблі наночастинок барвників із гідроксильним замісником, які зменшують інтенсивність свого світіння майже утричі завдяки перерозподілу негативного заряду в системі. Щоправда, в останньому випадку зазначені зміни відбуваються із певним латентним періодом. Поновлення початкової люмінесценції при цьому теж можливо лише після відпалу.

Висновки: Має місце певна селективність газочутливості барвників на базі комплексів 4-валентного стануму. Чутливими до аміаку і стійкими до парів $\mathrm{HCl}$ виявляються барвники із аміновим замісником, а чутливими до парів $\mathrm{HCl}$ і стійкими до аміаку є барвники із гідроксильним замісником. Тож перспективно використовувати у якості індикаторного люмінесцентного давача газу одночасно системи на базі обох ансамблів наночастинок: у разі необхідності кожна спрацює на відповідний газ.

Ключові слова: барвники, фотолюмінесценція, аміак, хлористий водень, давачі газу, екологія 